\title{
An Analysis of the Relationship between Victimization and Violent Behavior at School
}

\author{
(1) Universidad Miguel Hernández (Spain) \\ (2) Universidad de Zaragoza (Spain) \\ (3) Universidad Pablo de Olavide (Spain)
}

Estefanía Estévez (1), Teresa I. Jiménez (2), David Moreno (3) and Gonzalo Musitu (3)

\begin{abstract}
Previous studies have identified two subgroups of school violence victims: submissive and aggressive. Submissive victims are characterized by their withdrawal in violent situations, while aggressive victims combine hostile behavior with victimization. This study focuses on the second subgroup and aims to analyze possible factors influencing the transition from passive victimization to involvement in aggressive behaviors within the school context. To test these relationships, 1319 adolescents between 12 and 16 years of age were recruited from seven secondary schools in various Spanish provinces. Structural equation modeling techniques were used to analyze the data. Results supported Emler's theory, which posits that the victim's helplessness in situations of intimidation, along with disappointment resulting from a lack of expected protection from adult authority figures, may result in adolescents searching and developing an antisocial and non-conformist reputation that helps them defend themselves against future attacks. Practical implications of these results are further discussed.
\end{abstract}

Keywords: victimization, school violence, reputation, attitude towards authority.

Interest in the scientific study of school violence started in the 1980s with the pioneering work of psychologist Dan Olweus in Norway. Increases in the frequency and seriousness of violent behavior in European and American schools (Olweus, 2001; Skiba, 2000; Smith, 2003) provide justification for the concern of educators and researchers and their efforts to more deeply understand this complex and important social problem. The final goal of these studies has been to contribute to a detailed understanding of the problem and of the key players (attackers and victims) in order to help the planning of effective psychoeducational programs both for prevention and intervention of these maladjusted behaviors.

It is important to start by identifying the specific type of behavior to be analyzed in the present study, namely school violence. The term school violence has been used in numerous studies to refer to various types of behavior: aggression toward peers, aggression towards school staff, property damage, vandalism on campus, and bullying (Astor, Pitner, Benbenishty, \& Meyer, 2002; Herrero, Estévez, \& Musitu, 2006). Among all acts involving school violence, the current study focused on violence against peers, that is, on violence that entails the submission and victimization of one person by another one or group of people (i.e. other students).

Whereas most previous studies on peer violence have focused almost exclusively on aggression of a physical nature (sometimes including verbal aggression), the present work also examined relational violence. Relational violence has been defined as those actions aimed at causing damage within an individual's circle of friends, and those damaging an individual's perception of belonging to a group; this involves behaviors such as social exclusion and spreading of false rumors about the victim (Little, Henrich, Jones, \& Hawley, 2003). Recent studies have shown that this more covert, subtle and indirect form of violence may be as harmful to emotional adjustment of children and adolescents as more overt and direct forms of violence (Moreno, Estévez, Murgui, \& Musitu, 2009; Underwood, 2003). Given the importance of relational violence and the paucity of papers analyzing this variable in adolescence, the present study included a measure of violent behavior which provided information not only about physical and verbal victimization, but also about violence that is relational in nature.

\section{Antecedents of violent behavior}

The primary social contexts for adolescent's socialization play an essential role in behavioral adjustment in adolescence. Thus, exposure to family, school, and community violence has been linked to negative psychosocial adjustment and to the development of violent behaviors (Estévez, Musitu, \& Herrero, 2005; Murray \& Murray, 2004). For example, it has been observed that the quality of adolescent-parent and adolescent-teacher interactions influences and may determine the way adolescents perceive themselves in relation to others, their attitudes, and their behaviors (Jessor, 1991; Lila, Buelga, \& Musitu, 2006). Prior studies have shown that a negative family environment, characterized by high levels of family conflict (Cummings, Goeke-Morey, \& Papp, 2003), poor or negative communication with parents (Dekovic, Wissink, \& Mejier, 2004; Stevens, De Bourdeaudhuij, \& van Oost, 2002), and lack of perceived parental support (Sheeber, Hops, Alpert, Davis, \& Andrews, 1997), have a substantial and negative effect on the development of particular social skills in children, such as the capacity to 
identify non-aggressive solutions to interpersonal problems (Demaray \& Malecki, 2002; Lambert \& Cashwell, 2003).

Regarding the school context, being academically successful, perceiving peers in the classroom as friends or colleagues, and having positive interactions with teachers have been shown as important for the adolescent's psychosocial adjustment (Blankemeyer, Flannery, \& Vazsonyi, 2002; Reinke \& Herman, 2002). Students sharing these characteristics are likely to perceive school as a useful learning context that will help them construct a successful future as workers and citizens. Therefore, such students will not normally exhibit behavioral problems and will express positive attitudes towards teachers and school (Jack et al., 1996; Molpeceres, Lucas, \& Pons, 2000; Samdal, 1998). Conversely, having a negative attitude towards school staff and institution, as well as a negative social reputation among peers, have been consistently associated with antisocial and violent behavior in educational centres (Buelga, Musitu, Murgui, \& Pons, 2008; Emler \& Reicher, 1995, 2005; Musitu, Estévez, \& Emler, 2007).

Consistent with these findings, previous studies have observed a close relationship between attitude to police and the law, compliance with or rejection of the mainstream social norms, and subsequent antisocial and violent behavior in adolescence (Estévez, Murgui, Moreno, \& Musitu, 2007; Estévez \& Rachitskiy, 2009; Tarry \& Emler, 2007). A strong association between attitude to these authorities and victimization has also been reported, as suggested by Emler and Reicher $(1987,1995,2005)$ in their explanation of the processes by which victimization may lead to violent behavior.

\section{The victimization-aggression link}

It has been observed that all types of violence have subsequent negative effects on victims. In fact, the importance of examining adolescents who are victimized by their peers is justified by the numerous studies that have noted a close relationship between victimization and psychosocial adjustment problems in victims (Juvonen, Nishina, \& Graham, 2000; Kupersmidt, Coie, \& Dodge, 1990). Some studies found an association between being a victim of school violence and low self-esteem (Austin \& Joseph, 1996; Cava, Musitu, \& Murgui, 2007; Guterman, Hahm, \& Cameron, 2002). Other studies reveal that feelings of loneliness (Boivin, Hymel, \& Bukowski, 1995; Storch \& Masia-Warner, 2004), low satisfaction with life (Martin, Huebner, \& Valois, 2008), depressive symptoms and perceived stress are common among victimized adolescents (Herrero et al., 2006; Hunter, Mora-Merchán, \& Ortega, 2004; Sweeting, Young, West, \& Der, 2006; Kumpulainen, Räsänen, \& Puur, 2001). There are, therefore, numerous studies in the scientific literature showing a strong link between peer victimization and internalizing problems (see Hawker \& Boulton, 2000, for a meta- analysis), whilst only few works have considered victimization as a risk factor for the development of externalizing problems such as violence. In some longitudinal studies, it is concluded that physical and verbal victimization predicts aggressive and delinquent behavior (e.g., Hodges, Boivin, Vitaro, \& Bukowski, 1999; Paul \& Cillesen, 2003), and similar results have been observed in a recent cross-sectional research conducted by Sullivan, Farrel, and Kliewer (2006), who included relational victimization among the studied variables. Nevertheless, none of these studies gives a plausible or hypothetical explanation of the association between adolescent victimization and violence at school. Previous research using samples of adolescent offenders may offer an explanation that could be transferable to the school setting. Prior studies on the relationship between victimization, attitudes towards authority, and antisocial and criminal behavior served as the theoretical basis for our work. In this context, the studies carried out by Emler and Reicher over the past two decades have been particularly influential (1987, 1995, $2005,2009)$. These authors argue broadly that when a teenager is a victim of harassment or abuse or perceives themselves at risk or threatened by others, they rely on the protection of adult figures and institutions of authority. However, adults do not always provide perfect protection, which can result in the subsequent disappointment of the adolescent with these agents, and their search for an informal alternative to protect themselves from peer victimization. A possible initial solution, following the theory proposed by Emler and Reicher, is that the individual seeks a reputation based on a social image that conveys a non-conformist, rebellious and antisocial personality. This reputation includes the implicit idea that the person is strong, brave and ready to pursue violent revenge if attacked again. Finally, the authors conclude that the most effective strategy to develop this type of reputation is precisely the involvement in violent behaviors that exemplify what the teenager wants to convey about themselves. Thus, from this perspective, violence can be understood as a means to achieve the desired antisocial reputation, based on the idea that offenders cannot be victimized.

As such, it is reasonable to argue that experiencing peer victimization without the expected adult protection in the family or school contexts, can lead to negative attitudes towards the authority figures and the desire for a non-conforming reputation which would be associated with higher non-compliance with the established social norms. 


\section{The current study}

The current study was based on the theoretical explanation given by Emler and Reicher and argued extensively in Emler's 2009 work with adolescent delinquents, suggesting that peer victimization drives youth to act antisocially as a way to protect themselves when the authority figures fall short of that role. In the present research the focus fell on behavior at school. We considered these authors' hypothesis to be an appropriate starting point for the study of the processes involved in the relationship between victimization and violence in secondary schools and, ultimately, in the educational setting. In particular, the purpose of the present study was to analyze associations between school victimization and the development of violent behavior against peers. Moreover, the study was aimed to determine the role played by other possible intermediate variables in the understanding of the victimization-violence link. These variables were related to perception of the main adult protection figures and institutions for the adolescent, and in particular, to the family, school, and social justice systems. More concretely, we analyzed participants' perceptions of their parents and family environment (expressiveness-family communication, parent-child conflicts, and affective cohesion), their teachers and school institution (attitude towards school and teachers), and the police and legal institutions (attitude towards the police, laws and mainstream social norms). A measure of antisocial reputation among peers was also included in order to assess the degree of desirability of being perceived as a non-conformist, rebellious, violent person.

Figure 1 depicts the structural model proposed in the present study and based on Emler and Reicher's findings. The following relationships were expected to be found: an indirect association between victimization and violence, explained by (a) the victim's perception of adult authority figures and institutions represented in the family (parent), school (teachers) and general legal system (police and law), and (b) the relationship between attitude towards these authorities and the pursuit of an antisocial reputation.

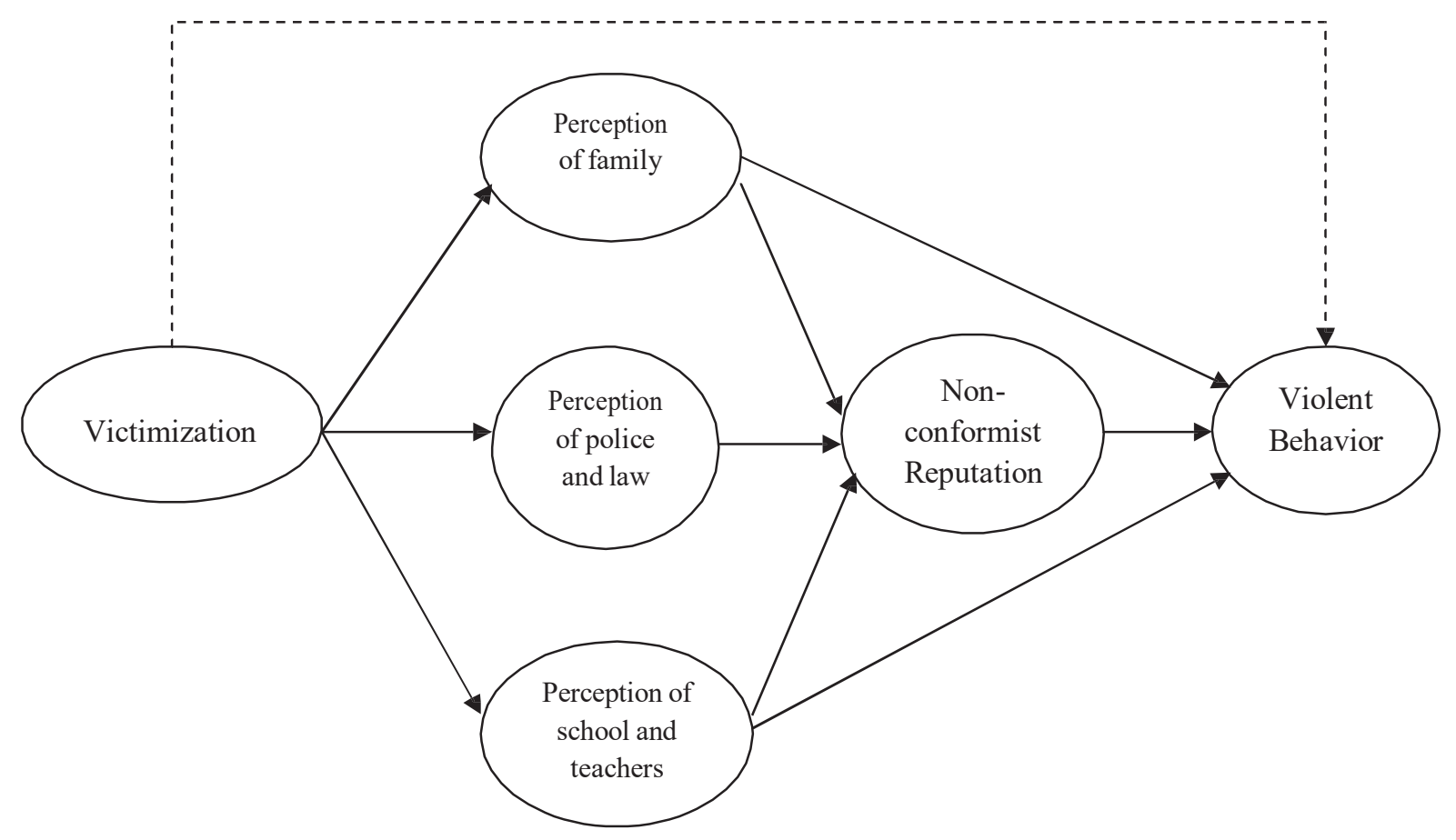

Figure 1. Structural model proposed based on Emler and Reicher's work.

\section{Methods}

\section{Participants}

A total of 1319 adolescents ( $47 \%$ male, 53\% female), between 12 and 16 years of age $\left(M_{\text {age }} 13.7, S D=1.6\right)$ participated in the study. At the time this study, all adolescents were enrolled in rural and urban state secondary schools located in the provinces of Valencia and Alicante in Spain. Comparative analyses did not show any statistically significant difference between rural and urban schools in the variables included in the present study. 


\section{Instruments}

Peer Victimization Scale (based on the Social Experience Questionnaire Self-Report from Crick \& Grotpeter, 1996; and the Multidimensional Peer-Victimization Scale from Mynard \& Joseph, 2000). This scale consisted of 20 items, each of which was rated on a four-point scale from 1 (never) to 4 ( many times), and referred to direct and indirect victimization at school. The scale has a three-factor structure: Overt physical victimization (composed of 7 items, e.g. "Some classmates have hit me"); Overt verbal victimization (composed of 7 items,

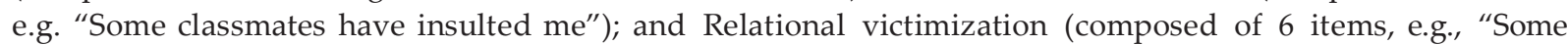
classmates have spread rumors about me so that nobody associates with $\left.\mathrm{me}^{\prime \prime}\right)$. This instrument has been used in previous studies with adolescent population, showing an adequate reliability and significant correlations with other indicators of psychosocial adjustment, such as perceived stress, depressive symptomatology, and feeling of loneliness (Cava et al., 2007; Cava, Musitu, Buelga, \& Murgui, 2010; Estévez. Murgui, \& Musitu, 2009; Jiménez, Musitu, Ramos, \& Murgui, 2009). Cronbach's alphas for the subscales in the current sample were .89 for overt physical victimization, .71 for overt verbal victimization, and .70 for relational victimization.

Relationship dimension of the Family Environment Scale (FES; Moos, Moos, \& Trickett, 1989). This scale consisted of 27 true-false items comprised of three subscales: (a) Cohesion ( 9 items referring to the degree of commitment and support that members of the own family provide for one another, e.g., "Family members really help and support one another"); (b) Expressiveness (9 items regarding the extent to which members of the own family are encouraged to express their feelings directly, e.g., "Family members often keep their feelings to themselves," reverse coded); (c) Conflict (9 items referring to the amount of openly expressed anger and conflict among family members, e.g., "We fight a lot in our family"). This scale has been widely used with adolescent population, showing an adequate internal consistency (Boyd, Gullone, Needleman, \& Burt, 1997; Chipuer \& Villegas, 2001). Alpha reliabilities for these subscales in this study were .85 for cohesion, .80 for expressiveness, and .86 for conflict. Regarding validity of the instrument, the cohesion and expressiveness subscales have shown positive correlations with measures of self-esteem, self-concept, empathic ability, and satisfaction with life (Escriva, García, \& Pérez-Delgado, 2001; Estévez, Murgui, Musitu, \& Moreno, 2008a, 2008b), and the conflict subscale has been related with measures of depression, anxiety, loneliness, and violent behavior in adolescence (Cava et al., 2010; Peleg-Popko, \& Klingman, 2002).

Attitude to Institutional Authority Scale (Reicher \& Emler, 1985). This scale consisted of 20 items, each of which was rated on a four-point scale from 1( I totally disagree) to 4 ( I totally agree), and referred to attitudes towards figures and institutions representing formal authority. This scale has a two-factor structure: Attitude towards teachers and school (composed of 10 items, e.g. "School rules are there to help the pupils", "A lot of teachers like bossing pupils around just to show they are in charge"); and Attitude towards the police and the law (composed of 10 items, e.g. "Most policemen are honest;" "The law is loaded against people like me"). The scale has shown adequate psychometric properties in previous studies (Emler, 1994; Emler \& Reicher, 1995, 2005; Tarry \& Emler, 2007). Cronbach's alphas for these subscales in the current sample were .76 and .65, respectively. As regards validity of the instrument, a positive attitude to institutional authority significantly correlates with measures of social integration at school, academic achievement, and self-esteem (Musitu et al., 2007). A negative attitude to authority has been significantly related to involvement in violent and delinquent behaviors in the school context (Estévez \& Emler, 2009).

Social Reputation Scale (Carroll, Hattie, Durkin, \& Houghton, 1999). This instrument consisted of seven items rated on a four-point scale from 1(never) to 4 (always) that assess the extent to which the respondent wants to convey a social image to peers as an antisocial and non-conformist person. All items begin with the phrase "I would like my classmates to believe that I..." (e.g., "get into trouble with the police," "am a bully," "do things against the law," "am rebellious"). This scale has been widely used in numerous studies with samples of adolescents, showing an adequate reliability (Carroll, 2002; Carroll, Hattie, Durkin, \& Houghton , 2001; Moreno et al., 2009). Cronbach's alpha obtained for the total score in this sample was .78. With respect to validity, significant positive correlations have been observed with violent and delinquent behavior and drugs consumption (Buelga, Musitu, \& Murgui, 2009; Carroll, Green, Houghton, \& Wood, 2003; Houghton, Odgers, \& Carroll, 1998), and negative correlations with indexes of self-esteem and life satisfaction (Buelga et al., 2008; Moreno et al., 2009). School Aggression Scale (Little et al., 2003). This instrument assessed the frequency with which participants had engaged in 24 deviant and aggressive behaviors at school over the last 12 months, on a fivepoint scale where 0 means (I don't want to share this information), 1 (never), and 4 (many times). Approximately $7 \%$ of respondents chose the " 0 " response for some items; these were removed from the analysis. The scale has a three factor structure: Overt Aggression (composed of 10 items, e.g., "I'm the type of person who hits, kicks, or punches others"); Relational Aggression (composed of 7 items, e.g., "If others have hurt me, I often try to keep them from being in my group of friends"); and Instrumental Aggression (composed of 7 items, e.g., "I often start fights to get what I want"). This instrument has been widely used in adolescent 
population, presenting excellent psychometric properties (Buelga et al., 2008; Little, Brauner, Jones, Nock, \& Hawley, 2003). Cronbach's alphas for these subscales in the current sample were .82 for overt aggression, .73 for relational aggression, and .78 for instrumental aggression. As regards validity, the three dimensions have shown significant correlations with measures of negative attitudes towards institutional authority, transgression of social norms, antisocial reputation, perceived stress, and dissatisfaction with life (Buelga et al., 2009; Estévez et al., 2008a; Jiménez, Moreno, Murgui, \& Musitu, 2008).

\section{Procedure}

Data for this research were collected as part of a larger study on adjustment problems in adolescence. After initial contacts were made with a large number of public schools, seven schools were selected as study sites. The selection was based primarily on the availability and willingness of school staff to collaborate in the investigation. Following initial contact with the principals, the entire teaching staff was informed of the study's objectives via a 2-hour presentation. A letter describing the study was then sent to the parents requesting that they indicate in writing if they did not want their child to participate in the study (only $1 \%$ of parents did so). Both the teachers and parents expressed a desire to be informed of the main results of the study in a meeting with the research team; and this occurred after data analyses were completed. Participants anonymously and voluntarily filled out the scales during a regular class period at the end of the academic year. All measures in English were translated to Spanish using bidirectional translation.

\section{Results}

Pearson correlations were calculated between all study variables, as a preliminary analysis of associations among dimensions of the selected instruments. These dimensions were considered as the observable variables for the latent factors included in the proposed structural model. Table 1 shows bivariate correlations with Bonferroni's corrections, as well as means and standard deviations for all variables. As significant correlations in the expected direction were observed, all variables were retained in subsequent analysis.

Using the Structural Equations statistical program (EQS), version 6.0 (Bentler, 1995), a structural equation model was calculated to deepen our comprehension of the interactions between the variables of interest, and to achieve a greater understanding of the processes involved in the development of hostile and aggressive behavior in victims of school violence. First, we calculated a structural model of the direct association between peer victimization and violent behavior at school. Figure 2 represents the model of direct effects which revealed a significant positive influence of victimization on violence, $\beta=.21, p<.001$. Next, a second model was estimated in order to analyze the association between victimization and violent behavior at school, while considering the perceived quality of family environment, attitude toward the school and teachers, attitude toward the police and laws, and non-conformist reputation among peers as influential intermediate variables. Figure 3 represents this structural model with the relationship coefficients and their statistical significance.

As presented earlier, the proposed structural model consisted of six factors, each of which was derived from several observable indicators or variables. The indicators correspond to the dimensions of the instruments used for data collection and described in the methods section. Latent factors included in the model were: (a) Victimization, composed of three indicators: physical victimization, verbal victimization and relational victimization, (b) Violent Behavior, composed of three indicators: overt violence, relational violence and instrumental violence; (c) Family Environment, composed of three indicators: conflict, expressiveness and cohesion, (d) Attitude toward school / teachers, consisting of a single indicator, (e) Attitude toward the police / law, consisting of a single indicator, and (6) Non- conformist Reputation, consisting of a single indicator. These last three factors, which consist of a single observable variable, were set to have a saturation factor of 1 and an error equal to 0 . Table 2 shows the factor loading of each variable on their corresponding latent factor. Factors relating to the perception of family, school and the legal system were calculated so that higher scores indicate negative perceptions by the adolescent. Table 3 gives correlations among the six latent factors. 


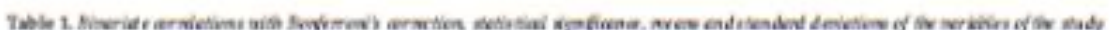

\begin{tabular}{|c|c|c|c|c|c|c|c|c|c|c|c|c|}
\hline Vartakle & $\mathbf{t}$ & 2 & 3 & 4 & $\mathbf{s}$ & 6 & 7 & a & 9 & wi & 11 & 12 \\
\hline 1. Wethi Wretminaren & 1 & & & & & & & & & & & \\
\hline 2. Trsical videlmersion & $603 \times 9$ & $\mathrm{t}$ & & & & & & & & & & \\
\hline 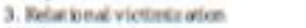 & 39009 & $\sec (m)$ & 1 & & & & & & & & & \\
\hline 4. Aandly Cathenton & $-119(-)$ & -15009 & $-104+4$ & 1 & & & & & & & & \\
\hline 5. Nandif Bepeoirenes & $-\operatorname{sech}$ & -10 & $-\operatorname{\theta nc}(9)$ & A5079 & 1 & & & & & & & \\
\hline 6. Rarnly Cenfliet & $1260^{* 5}$ & $\left.\ln ()^{\prime}\right)$ & Haven & $-5 x=1$ & $-20 x=1$ & 1 & & & & & & \\
\hline 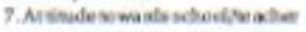 & -eifs $(-)$ & $-10 \times x^{* 5}$ & -6709 & 27205 & 17009 & -100 & 1 & & & & & \\
\hline 8. Artmade we waste policentaw & $-001(-)$ & $-12 x+9$ & $-\operatorname{esa} 9$ & $2 m \%$ & 11305 & -.1010 & sutes & 1 & & & & \\
\hline 9 Anstiocial npustaten & ait & $\operatorname{ses}(9)$ & $\sin$ & $-16 x=1$ & $-\operatorname{anc}=3$ & 1ex-7 & $-300^{+5}$ & $-332+9$ & $\mathrm{I}$ & & & \\
\hline 10 Ovet visiomos & $23 \mathrm{mas}$ & $20(\mathbf{m})$ & sares & $-20=y$ & $-104=$ & $200-5$ & $-x x^{2}=$ & $-22 a^{* 5}$ & 34209 & 1 & & \\
\hline 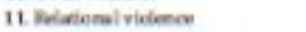 & 12609 & $15 a(m)$ & $16 \times 29$ & $-25 x-3$ & $-114(-)$ & 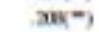 & $-355^{-1}$ & $-30^{+5}$ & $348+5$ & ases? & 1 & \\
\hline 12 monumetal volines & 37005 & $\mathbf{m}(\boldsymbol{m})$ & 2800 & $-22 x=1$ & $-112(-)$ & 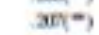 & $-30 x+5$ & $-3 x+5$ & 30005 & $\operatorname{ces} 25$ & smen & 1 \\
\hline Mean & 97 & $4=$ & 1656 & 1562 & 1618 & 1211 & 1251 & 115 & me & 1226 & 1417 & 1371 \\
\hline Sturubat Deriation & 3 ag & 18 & $5 \%$ & 244 & 199 & $2 x$ & 231 & 211 & 24 & $1 \mathrm{~m}$ & 267 & 234 \\
\hline
\end{tabular}

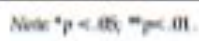

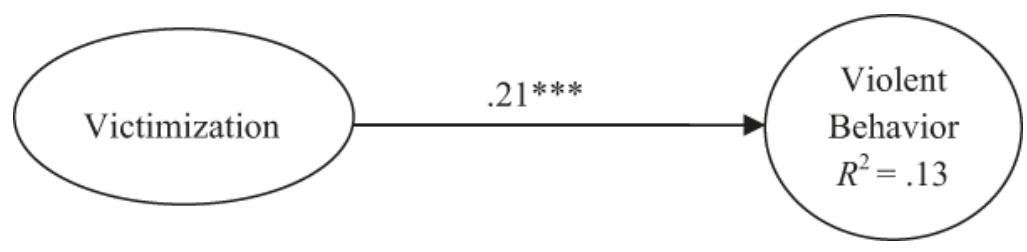

Figure 2. Model of direct effects of victimization on violent behavior ${ }^{* * *} p<.001$.

Table 2. Factor Loadings, Standard Errors and Associated Probability.

\begin{tabular}{lc}
\hline Variables & Factor Loadings \\
\hline Victimization & \\
$\quad$ Verbal victimization & $1^{\mathrm{a}}$ \\
Physical victimization & $.663^{* *}(.031)$ \\
Relational victimization & $.958^{* *}(.034)$ \\
Family Environment & \\
Conflict & $1^{\mathrm{a}}$ \\
Expressiveness & $.531^{* *}(.46)$ \\
Cohesion & $.677^{* *}(.51)$ \\
Attitude school/teachers & $1^{\mathrm{a}}$ \\
Attitude police/lazs & $1^{\mathrm{a}}$ \\
Ideal Reputation & $1^{\mathrm{a}}$ \\
Manifested Violence & \\
Overt Violence & $1^{\mathrm{a}}$ \\
Relational Violence & $.904^{* *}(.040)$ \\
Instrumental Violence & $.906^{* *}(.037)$ \\
\hline
\end{tabular}

Note: ${ }^{\text {a }}$ Fixed at 1.00 during the estimation. Significance:

** $p<.01$.

To determine the goodness of fit of the model and the statistical significance of the coefficients and because of the deviation from normality of the data (normalized Mardia coefficient: 6.38), robust estimators and several indexes were used. For the chisquare likelihood-ratio statistics, a non-significant value indicates that the model is well adjusted to the data. However, since this fit index is very sensitive to the sample size, other fit indexes must be considered when testing goodness of fit. Comparative Fit Index (CFI), Incremental Fit Index (IFI), Non-Normed Fit Index (NNFI), and Root Mean Square Error of Approximation (RMSEA) are widely used. For the CFI, IFI and NNFI indexes, values above 0.90 are considered acceptable (Marsh \& Hau, 1996; Medsker, Williams, \& Holahan, 1994), although other authors argue that only more stringent values -above 0.95- are indicative of a good fit (Batista \& Coenders, 2000). For the RMSEA index, although values below .08 are accepted in some manuals, there is consensus that a ratio below .05 indicates good model fit (Browne \& Cudeck, 1992). The structural model calculated fitted the data well, as suggested by the 
Table 3. Bivariate correlations among latent factors included in the structural model

\begin{tabular}{|c|c|c|c|c|c|c|}
\hline Variables & 1 & 2 & 3 & 4 & 5 & 6 \\
\hline 1. Victimization & 1 & & & & & \\
\hline 2. Negative family environment & $.225(* *)$ & 1 & & & & \\
\hline 3. Negative attitude to school and teachers & $.079\left(^{*}\right)$ & $.202(* *)$ & 1 & & & \\
\hline 4. Negative attitude to police and law & $.065\left(^{*}\right)$ & $.251(* *)$ & $.504(* *)$ & 1 & & \\
\hline 5. Non-conformist reputation & $.080\left(^{*}\right)$ & $\left..355{ }^{* *}\right)$ & $.312(* *)$ & $.457(* * *)$ & 1 & \\
\hline 6. Violent behavior & $.196(* *)$ & $.339\left(^{* *}\right)$ & $.354(* *)$ & $.355\left(^{* *}\right)$ & $.562\left({ }^{* * *}\right)$ & 1 \\
\hline
\end{tabular}

Note: ${ }^{*}<.05 ;{ }^{* *} p<.01 ;{ }^{* *} p<.001$.

following indexes: $\chi^{2}(55, N=1319)=164.18(p<.01), \mathrm{CFI}=.97, \mathrm{IFI}=.97, \mathrm{NNFI}=.96$, and RMSEA $=.47$. In all cases, rates obtained in the present study were indicative of a good fit of the structural model depicted in Figure 2. This figure shows the standardized coefficients of relation and their associated probability.

This model explained $35 \%$ of the variance of the final variable, Violent Behavior. The results of the model showed an indirect relationship between victimization and violent behavior. The direct association between these two variables was not significant when the other latent factors were introduced into the equation.

Regarding interactions between variables that explain the indirect relationship between victimization and violence, we observed a significant and positive relationship between the experience of being victimized and each of the following: the adolescent's perception of a negative family environment, $\beta=.21, p<.001$, their negative attitude toward the police and the law, $\beta=.10, p<.05$, and their negative attitude towards the school and teachers, $\beta=.12, p<.001$. In turn, these last three factors showed a direct and positive relation- ship with the adolescent's non-conformist reputation among peers, $\beta=.12, p<.001 ; \beta=.29, p<.001$, and $\beta=.24, p<$ .001 , respectively. That is to say, the results indicated that the negative perception of authority figures and institutions such as family, school and police, was positively associated with the adolescent's intention to set up and maintain an antisocial and non- conformist reputation among peers.

n.s.

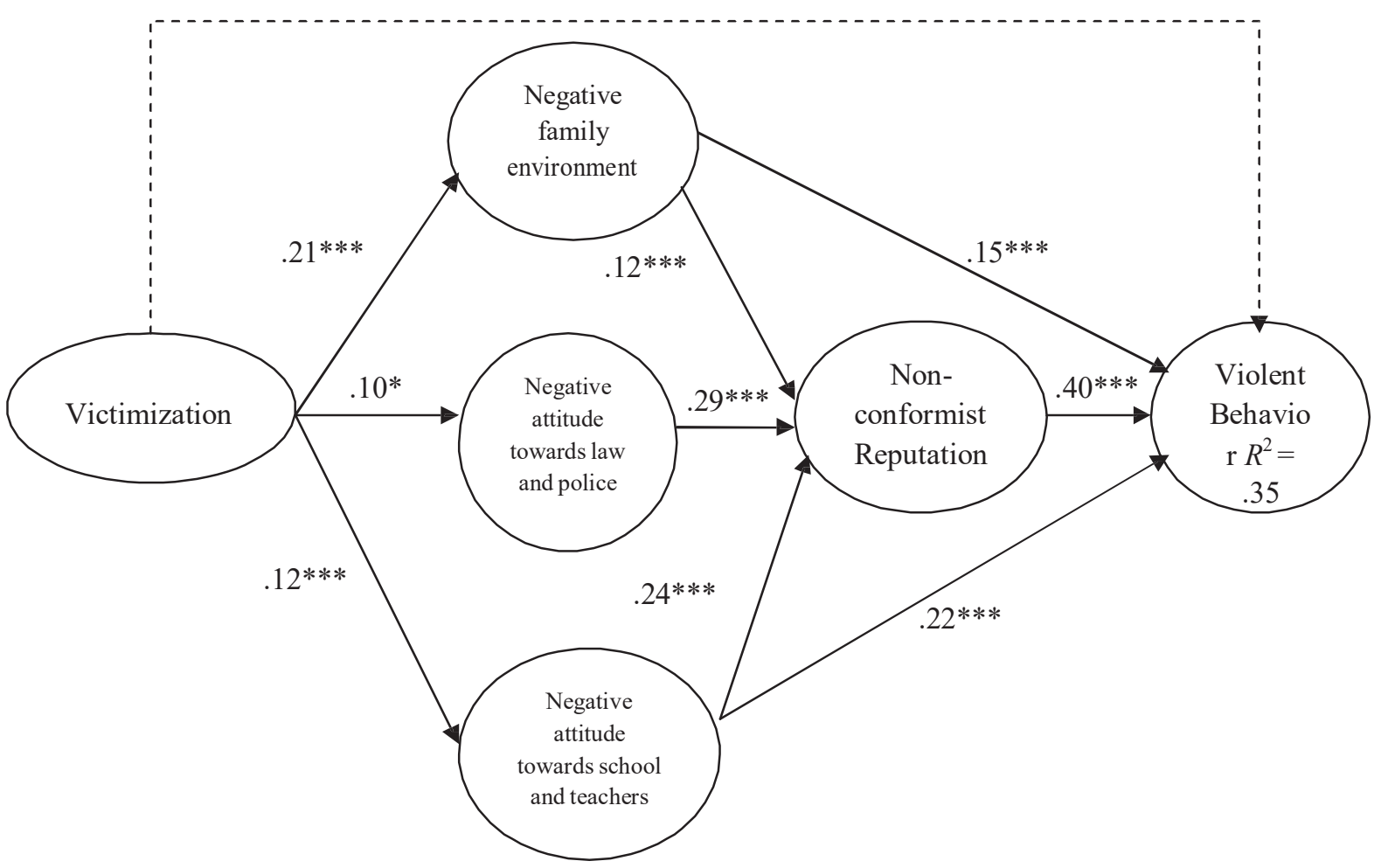

Figure 3. Final structural model including the relationship coefficients and their statistical significance values. ${ }^{*} p<.05 ;{ }^{* *} p<.01$; ${ }^{* * *} p<.001 ;$ n.s. $=$ non significant. 
Finally, there was a strong positive relationship between non-conformist reputation and violent behavior at school, $\beta=.40, p<.001$. Furthermore, the model also showed the existence of significant direct relationships between the perception of a negative family environment, on the one hand, and negative attitudes toward school and teachers, on the other hand, with violent behavior, $\beta=.15, p<.001$, and $\beta=.22, p<$ .001 , respectively.

To further check the robustness of this model we tested it using structural invariance across gender and age groups (early adolescence: 12-14; middle adolescence: 15-16) through multigroup analyses (Bentler \& Wu, 2002). Two models were tested in each case. In the unrestricted model, parameter estimates (factor loadings and structural paths) were freely estimated across groups; in the restricted model, we constrained each of the factor loadings as well as the structural paths to be invariant across groups. If the $\chi^{2}$ of the restricted model was significantly larger than the $\chi^{2}$ of the unrestricted model, the assumption of invariance would not be tenable. Results indicated non- significant differences between these models for boys and girls: $\chi^{2}(20, N=1319)=$ $31.48, n s ;$ and for age groups: $\chi^{2}(12, N=1319)=19.99, n s$; this result supported, therefore, invariance of the general model across gender and age groups.

\section{Discussion}

The present study aimed to analyze the role played by particular variables associated with adolescent psychosocial adjustment in explaining the process that may trigger a victim of school violence to respond aggressively toward peers. Following the theory proposed by Emler (2009), we expected to find an indirect relationship between victimization and violence, once certain intermediate variables related to the adolescent's perception of authority figures and institutions (such as the family, school and police) were included in the model. Our results with a sample of Spanish students in relation to peer victimization and violence among peers were consistent with the conclusions drawn by Emler and Reicher from their studies with young offenders in the UK.

In particular, our results stressed the importance of the victims' evaluation of their immediate social contexts and their principal authority figures and institutions, such as family, school and the legal system; these are the authority agents required to perform a protective role and to propose solutions to the situation of victimization. The observed relationships in the model suggest that when the victim does not rely on receiving support and comfort from parents, teachers and other authority figures as police, they are more likely to opt for selfprotection through the configuration of an antisocial and non-conformist reputation. This self-representation eventually results in violent behaviors that reinforce such social image.

Recent studies provide data that are consistent with this idea. Leadbeater, Boone, Sangster, and Mathieson (2006) found that although most of victims in their sample presented higher levels of social rejection compared with average and aggressive adolescent groups, only the more submissive victims showed statistically significant differences in popularity compared to victims who were also aggressive, that is, violent victims were as popular as aggressors or non-involved adolescents. This fact suggests that victims who decide to behave aggressively have a clearly defined reputational project among their peers, that is to say, they search for a particular social image at school, which is reflected in their degree of popularity. In addition, Estévez, Martínez, and Musitu (2006) found that victims who are also violent reported higher levels of social self-esteem and fewer feelings of loneliness than withdrawn victims. These results indicate that some victims feel more supported by their social network of friends, a network that probably contributes to maintaining the individual's reputation and the adolescent's behavioral style at school.

Previous research has highlighted the close association between the fact of having been victimized and criminal behavior (Shafer \& Ruback, 2002; Wiebush, Freitag, \& Baird, 2001). However, these studies have been conducted exclusively in a delinquent population and in very specific contexts, mainly in the United Kingdom and the United States. Research in other European countries is in its infancy, especially if we consider the school-aged population that jointly presents both victimization and aggression problems, and therefore, are at high risk of psychosocial maladjustment. We feel that it is imperative that future research continues to examine the particular situation of some victims of school violence, both in their individual characteristics and in the particularities of the immediate social contexts for the teenager, since the victim's perception of adult authority and protection figures is a key determinant of this phenomenon, as our results have indicated.

Parents and teachers seem to be the most influential adult figures in this sense. In fact, our findings revealed that when peer victimization negatively affects adolescent's attitudes towards family and school, those negative perceptions and attitudes may directly affect the student's behavior. Taking into consideration Emler's (2009) argument followed in the present work, children and adolescents obey the socially established norms and 
rules because they rely on adults -parents, teachers...-, but in exchange for this obedience and trust, they expect that the those adults will advocate for their respectful treatment and will respond with the support and protection required in such situations, since they represent agents of authority and power. Suggestions for future school intervention programs would also include to help young people in situations of victimization to feel supported instead of frustrated, helpless and unprotected. Along this line, a positive family environment based on empathy and emotional communication between parents and children has been identified in the scientific literature as a major protective factor against the development of aggressive behavior in adolescence (Estévez et al., 2008; Stevens et al., 2002). Similarly, the perception of a positive school climate in which the adolescent values the relationship with peers and teachers from whom he receives care and support, has been linked with the presence of less aggression problems at school (Blankemeyer et al., 2002; Jiménez et al., 2008). Therefore, research along these lines continues to be fundamental in order to give more appropriate responses for the victims and perpetrators, and ultimately help prevent victimization in schools.

Finally, the authors acknowledge several limitations of the present study. First, all data collection instruments used in this work were self-report measures. These self-report measures may be more susceptible to response biases that could undermine the validity and generalizability of the data. They also have, however, many advantages: they allow for the gathering of significant information in a short amount of time and facilitate the interpretation of results without inferences. Although it would have been advisable to gather information from other informants (e.g., teachers) to contrast the data self-reported by adolescents, the main objective of this study was to examine the subject's perception of their social status in the school context and of the authority figures and institutions. In addition, some comparative studies of deviant behavior measures using different informants (e.g., teenagers and parents) have demonstrated validity of self-report instruments, regardless of the source of information (Flisher, Evans, Muller, \& Lombard, 2004; Kamphaus \& Frick, 2005; Ritakallio, KaltialaHeino, Kivivuori, \& Rimpelä, 2005). Kamphaus \& Frick (2005) suggest that adolescents are much more accurate in their reports of many acts, as parents may not be aware of the frequency or extent of their child's deviant behavior.

In a recent study carried out by Barry, Frick, and Grafeman (2008) using a sample of adolescents with problem behavior, the authors highlight that parent's reports of police contacts, which were used as a comparative measure with self-reports, did not provide the breadth of information included in their child's reports. Other recent studies point out that both self-reports and official reports are essential to a more complete understanding of which adolescents are in greatest danger of the most serious forms of violence (USDHHS, 2001; Snyder \& Sickmund, 1999). To sum up, authors of the present study, taking into consideration the studies mentioned, believe that the use of self-report measures may be a limitation, but that it is also a great opportunity for data collection and interpretation of findings.

A second limitation of this study is that not all values obtained for the reliability measure Cronbach's alpha in the scales and subscales used, are as high as recommended. Most statistical manuals, books and journal articles indicate that a value of .7 or .8 is acceptable for Cronbach's alpha; values substantially lower indicate an unreliable scale or subscale (Field, 2005; Kline, 1999). One of the subscale used in the current study obtained a value lower than .7 (attitude towards the police and the law, $\alpha=.65$ ).

Finally, this study is based on a cross-sectional design, which forces us to be cautious about the causal inferences drawn from the results. Due to the correlational nature of the statistical analysis, including the estimated structural equation model, we cannot establish direct causal relationships between the variables presented. With the data available it is also plausible that variables relate in the opposite direction, so that violent behavior could lead to a non-conformist reputation and a negative family environment. In order to clarify and sustain with more reliability the direction of these associations, it would be necessary to conduct a more complete study that comprises measures across time. Thus, future research should incorporate a longitudinal design in order to achieve a more comprehensive understanding of the processes involved in the development of violent behavior in victimized adolescents. Definitively, with the data obtained in the present study, we must consider the possibility of bidirectional links between the constructs analyzed.

In fact, although there are no previous studies in the school context regarding the relations discussed herein, research on samples of delinquent adolescents suggests the existence of bidirectional links between victimization and deviant behavior. For example, adolescents involved in antisocial acts have been found to be three times more likely to be victims (Deadman \& MackDonald, 2004; Lauritsen, Sampson, \& Laub, 1991). This result follows with the assumptions of the Lifestyle Exposure Theory (Hinderlang, Gottfredson, \& Galofalo, 1978) and the Routine Activities Theory (Cohen \& Felson, 1979). According to these criminological theories, being a victim of crime is usually linked to exposure or proximity to offender populations on the one hand, and offenders are also more likely to become victims of crime because their lifestyles frequently bring them to interact with other offenders, on the other hand (Sampson \& Lauritsen, 1990). From our point of view, it would be highly recommended for future research in schools to consider these arguments derived from juvenile delinquent studies. 


\section{References}

Astor R., Pitner R. O., Benbenishty R., \& Meyer H. A. (2002). Public concern and focus on school violence. In L. A. Rapp-Paglicci, A. R. Roberts, \& J. S. Wodarski (Eds.), Handbook of violence. New York, NY: Wiley.

Austin S., \& Joseph S. (1996). Assessment of bully/victim problems in 8 to 11 years old. British Journal of Educational Psychology, 66, 447-456. http://dx.doi.org/10.1111/ j.2044-8279.1996.tb01211.x

Barry C. T., Frick P. J., \& Grafeman S. J. (2008). Child versus parent reports of parenting practices: Implications for the conceptualization of child behavioral and emotional problems. Assessment, 15, 294-303.

http://dx.doi.org/10.1177/1073191107312212

Batista J. M., \& Coenders G. (2000). Modelos de ecuaciones estructurales [Structural Equations Models]. Madrid, Spain: La Muralla.

Bentler P. M. (1995). EQS structural equations program manual. Encino, CA: Multivariate Software.

Bentler P., \& Wu E. (2002). EQS 6 for windows user's guide. Encino, CA: Multivariate Software.

Blankemeyer M., Flannery D. J., \& Vazsonyi A. T. (2002). The role of aggression and social competence in children's perceptions of the child-teacher relationship. Psychology in the Schools, 39, 293-304. http://dx.doi.org/10.1002/ pits.10008

Boivin M., Hymel S., \& Bukowski W. M. (1995). The roles of social withdrawal, peer rejection, and victimization by peers in predicting loneliness and depressed mood in children. Development and Psychopathology, 7, 765-785.

http://dx.doi.org/10.1017/S0954579400006830

Boyd C. P., Gullone E., Needleman G. L., \& Burt T. (1997). The Family Environment Scale: Reliability and normative data for an adolescent sample. Family Process, 36, 369-373. http://dx.doi.org/10.1111/j.1545-5300.1997.00369.x

Browne M. W., \& Cudeck R. (1992). Alternative ways of assessing model fit. Sociological Methods and Research, 21, $230-258$. http://dx.doi.org/10.1177/0049124192021002005

Buelga S., Musitu G., \& Murgui S. (2009). Relaciones entre la reputación social y la agresión relacional en la adolescencia [Relations between social reputation and relational aggression in adolescence]. International Journal of Clinical and Health Psychology, 9, 127-141.

Buelga S., Musitu G., Murgui S., \& Pons J. (2008). Reputation, loneliness, satisfaction with life and aggressive behavior in adolescence. The Spanish Journal of Psychology, 11, 192-200.

Carroll A. (2002). At-risk and not at-risk adolescent girls in single-sex and mixed-sex school settings: An examination of their goals and reputations. Westminster Studies in Education, 25, 147-162. http://dx.doi.org/10.1080/0140672020250205

Carroll A., Green S., Houghton S., \& Wood R. (2003). Reputation enhancement and involvement in delinquency among high school students. International Journal of Disability, Development and Education, 50, 253-273. http://dx.doi.org/10.1080/1034912032000120444

Carroll A., Hattie J., Durkin K., \& Houghton S. (1999). Adolescent reputation enhancement: Differentiating delinquent, nondelinquent, and at-risk youths. Journal of Child Psychology and Psychiatry, 40, 593-606. http://dx.doi.org/10.1111/1469-7610.00476

Carroll A., Hattie J., Durkin K., \& Houghton S. (2001). Goal setting and reputation enhancement: Behavioral choices among delinquent at-risk and not at-risk adolescents. Legal and Criminological Psychology, 6, 165-184. http://dx.doi.org/10.1348/135532501168262

Cava M. J., Musitu G., Buelga S., \& Murgui S. (2010). The relationships of family and classroom environments with peer relational victimization: An analysis of their gender differences. The Spanish Journal of Psychology, 13, 156-165.

Cava M. J., Musitu G., \& Murgui S. (2007). Individual and social risk factors related to overt victimization in a sample of Spanish adolescents. Psychological Reports, 101, 275-290. http://dx.doi.org/10.2466/pr0.101.1.275-290

Chipuer H. M., \& Villegas T. (2001). Comparing the second-order factor structure of the Family Environment Scale across husbands' and wives' perceptions of their family environment. Family Process, 40, 187-198. http://dx.doi.org/10.1111/j.1545-5300.2001.4020100187.x

Cohen L., \& Felson M. (1979). Social change and crime rate trends: A routine activities approach. American Sociological Review, 44, 588-608. http://dx.doi.org/10.2307/2094589

Crick N. R., \& Grotpeter J. K. (1996). Children's treatment by peers. Victims of relational and overt aggression. Development and Psychopathology, 8, 367-380. http://dx.doi. org/10.1017/S0954579400007148

Cummings M. E., Goeke-Morey M. C., \& Papp L. M. (2003). Children's responses to everyday marital conflict tactics in the home. Child Development, 74, 1918-1929. http://dx.doi. org/10.1046/j.1467-8624.2003.00646.x

Deadman D., \& MacDonald Z. (2004). Offenders as victims of crime?: An investigation into the relationship between criminal behavior and victimization. Journal of the Royal Statistical Society, 167, 53-67. http://dx.doi.org/10.1111/ j.1467985X.2004.00291.x

Demaray M.P., \& MaleckiC. K. (2002). The relationship between perceived social support and maladjustment for students at risk. Psychology in the Schools, 39,305-316. http://dx.doi.org/10.1002/pits.10018

Dekovic M., Wissink I., \& Meijer A. (2004). The role of family and peer relationsin adolescent antisocial behavior: Comparison of four ethnic groups. Journal of Adolescence, 27, 497-514. http://dx.doi.org/10.1016/j.adolescence.2004.06.010

Emler N. (1994). The young person's relationship to the institutional order. In S. Jackson \& H. Rodriguez Tome (Eds.), The social worlds of adolescents (pp. 229-250). Hillside, NJ: Erlbaum.

Emler N. (2009). Delinquents as a minority group: Accidental tourists in forbidden territory or voluntary émigrés? In F. Butera \& J. Levine (Eds.), Coping with minority status: Responses to exclusion and inclusion (pp. 127-154). Camdridge, UK: Cambridge University Press. 
Emler N., \& Reicher S. (1987). Orientations to institutional authority in adolescence. Journal of Moral Education, 16, 108-116. http://dx.doi.org/10.1080/0305724870160203

Emler N., \& Reicher S. (1995). Adolescence and delinquency. Oxford, UK: Blackwell Publishers Ltd.

Emler N., \& Reicher S. (2005). Delinquency: Cause or consequence of social exclusion? In D. Abrams,

M. A. Hogg, \& J. M. Marques (Eds.), The social psychology of inclusion and exclusion (pp. 211-241). New York, NY: Psychology

Press.

Escriva M. V., García P. S., \& Pérez-Delgado E. (2001). Family climate and the development of self-concept. A longitudinal study in adolescent population. Revista Latinoamericana de Psicología, 33, 243-259.

Estévez E., \& Emler N. (2009). Individual differences in attitude to school and social reputation among peers: Implications for behavioral adjustment in educational settings. In J. E. Larson (Ed.), Educational psychology: Cognition and learning, individual differences and motivation (pp. 342-375). New York, NY: Nova Science Publishers.

Estévez E., Martínez B., \& Musitu G. (2006). La autoestima en adolescentes agresores y víctimas en la escuela: La perspectiva multidimensional [Self-esteem in aggressors and victims at school: A multidimensional perspective]. Intervención Psicosocial, 15, 32-41. http://dx.doi. org/10.4321/S1132-05592006000200007

Estévez E., Murgui S., Moreno D., \& Musitu G. (2007). Family communication styles, attitude towards institutional authority and adolescents' violent behavior at school. Psicothema, 19, 108-113.

Estévez E., Murgui S., \& Musitu G. (2009). Psychosocial adjustment in bullies and victims of school violence. European Journal of Psychology of Education, 24,473-483. http://dx.doi.org/10.1007/BF03178762

Estévez E., Murgui S., Musitu G., \& Moreno D. (2008a). Adolescent aggression: Effects of gender and family and school environments. Journal of Adolescence, 31, 433-450. http://dx.doi.org/10.1016/j.adolescence.2007.09.007

Estévez E., Murgui S., Musitu G., \& Moreno D. (2008b). Clima familiar, clima escolar y satisfacción con la vida en adolescents [Family climate, school climate and life satisfaction in adolescents]. Revista Mexicana de Psicología, 25, 119-128.

Estévez E., Musitu G., \& Herrero J. (2005). The influence of violent behavior and victimization at school on psychological distress: The role of parents and teachers. Adolescence, 40, 183-195.

Estévez E., \& Rachitskiy M. (2009). Violent and delinquent youths: Relationships with institutional authorities and compliance with social norms. In N. A. Ramsay \& C. R. Morrison (Eds.), Youth violence and juvenile justice: Causes, intervention and treatment programs (pp. 158-180). New York, NY: Nova Publishers.

Field A. (2005). Discovering statistics using SPSS. London, UK: Sage Publications.

Flisher A. J., Evans J., Muller M., \& Lombard C. (2004). Brief report: Test-retest reliability of self-reported adolescent risk behavior. Journal of Adolescence, 27, 207-212. http://dx.doi.org/10.1016/j.adolescence.2001.10.001

Guterman N. B., Hahm H. C., \& Cameron M. (2002). Adolescent victimization and subsequent use of mental health counseling services. Journal of Adolescent Health, 30, 336-345. http://dx.doi.org/10.1016/S1054-139X(01)00406-2

Hawker D. S. J., \& Boulton M. J. (2000). Twenty years' research on peer victimization and psychosocial maladjustment: A meta-analytic review of cross-sectional studies. Journal of Child Psychology and Psychiatry, 41, 441-455. http://dx.doi.org/10.1111/1469-7610.00629

Herrero J., Estévez E., \& Musitu G. (2006). The relationships of adolescent school-related deviant behavior and victimization with psychological distress: Testing a general model of the mediational role of parents and teachers across groups of gender and age. Journal of Adolescence, 29, 671-690. http://dx.doi.org/10.1016/ j.adolescence.2005.08.015

Hinderlang M., Gottfredson M., \& Garofalo J. (1978). Victims of personal crime: An empirical foundation for a theory of personal victimization. Cambridge, MA: Ballinger.

Hodges E., Boivin M., Vitaro F., \& Bukowski W. M. (1999). The powerof friendship: Protectionagainstanescalating cycle of peer victimization. Developmental Psychology, 35, 94-101. http://dx.doi.org/10.1037//0012-1649.35.1.94

Houghton S., Odgers P., \& Carroll A. (1998). Reputations, self-concepts and coping strategies of volatile solvent users. Journal of Drug Education, 28, 199-210. http://dx. doi.org/10.2190/6FUR-7X21-97EX-P36N

Hunter S. C., Mora-Merchán J., \& Ortega G. (2004). The long-term effects of coping strategy use in victims of bullying. The Spanish Journal of Psychology, 7, 3-12.

Jack S. L., Shores R. E., Denny R. K., Gunter P. L., DeBriere T., \& DePaepe P. (1996). An analysis of the relationships of teachers' reported use of classroom management strategies on types of classroom interactions. The Journal of Behavioral Education, 6, 67-87. http://dx.doi.org/10.1007/BF02110478

Jessor R. (1991). Risk behavior in adolescence: A psychosocial framework for understanding and action. Journal of Adolescent Health, 12, 597-605. http://dx.doi.org/10.1016/1054-139X(91)90007-K

Jiménez T. I., Moreno D., Murgui S., \& Musitu G. (2008). Factores psicosociales relacionados con el estatus social del alumno en el aula: El rol de la reputación social, la amistad, la conducta violenta y la relación con el profesor [Psychosocial factors related to student's social status in the classroom: The role of social reputation, friendship, violent behavior, and relationship with teacher]. International Journal of Psychology and Psychological Therapy, 8, 227-236.

Jiménez T. I., Musitu G., Ramos M. J., \& Murgui S. (2009). Community involvement and victimization at school: An analysis through family, personal and social adjustment. The Journal of Community Psychology,37, 959-974. http://dx.doi.org/10.1002/jcop.20342

Juvonen J., Nishina A., \& Graham S. (2000). Peer harassment, psychological adjustment, and school functioning in early adolescence. Journal of Educational Psychology, 92, 349-359. http://dx.doi.org/10.1037//0022-0663.92.2.349

Kamphaus R. W., \& Frick P. J. (2005). Clinical assessment of child and adolescent personality and behavior (2 ${ }^{\text {nd }}$ Ed.). New York, NY: Springer. http://dx.doi.org/10.1037//0022-0663.92.2.349

Kline P. (1999). The handbook of psychological testing. London, UK: Routledge. 
Kumpulainen K., RäsänenE., \&Puura K. (2001). Psychiatric disorders and the use of mental health services among children involved in bullying. Aggressive Behavior, 27, 102-110. http://dx.doi.org/10.1002/ab.3

Kupersmidt J. B., Coie J. D., \& Dodge K. A. (1990). Predicting disorder from peer social problems. In S.R. Asher \& J.D. Coie (Eds.), Peer rejection in childhood. New York, NY: Cambridge University Press.

Lambert S. F., \& Cashwell C. S. (2003). Preteens talking to parents: Perceived communication and school-based aggression. The Family Journal: Counseling and Therapy for Couples and Families, 12, 122-128. http://dx.doi.org/ 10.1177/1066480703261953

Lauritsen J. L., Sampson R. J., \& Laub J. H. (1991). The link between offending and victimization among adolescents. Criminology, 29, 265-292. http://dx.doi.org/10.1111/ j.1745-9125.1991.tb01067.x

Lea dbeater B. J., Boone E. M., Sangster N. A., \& Mathieson L. C. (2006). Sex differencesin the personal costs and benefits of relational and physical aggression in high school. Aggressive Behavior, 32, 409-419. http://dx.doi.org/10.1002/ab.20139

Lila M., Buelga S., \& Musitu G. (2006). Las relaciones entre padres e hijos en la adolescencia [Relationships between parents and children in adolescence]. Madrid, Spain: Pirámide.

Little T., Brauner J., Jones S., Nock M., \& Hawley P. (2003). Rethinking aggression: A typological examination of the functions of aggression. Merrill-Palmer Quarterly, 49, 343-369. http://dx.doi.org/10.1353/mpq.2003.0014

Little T. D., Henrich C. C., Jones S. M., \& Hawley P. H. (2003). Disentangling the "whys" from the "whats" of aggressive behavior. International Journal of Behavioral Development, 27, 122-133. http://dx.doi.org/10.1080/01650250244000128

Marsh H. W., \& Hau K. T. (1996). Assessing goodness of fit: Is parsimony always desirable? Journal of Experimental Education, 64, 364-390.

Martin K., Huebner E. S., \& Valois R. F. (2008). Does life satisfaction predict victimization experiences in adolescence? Psychology in the Schools, 45,705-714. http://dx.doi.org/10.1002/pits.20336

Medsker G. J., Williams L. J., \& Holahan P. J. (1994). Areview of current practicesfor evaluating causal-modelsin organizationalbehavior and human-resources management research. Journal of Management, 20, 439-464.

http://dx.doi.org/10.1177/014920639402000207

Molpeceres M. A., Lucas A., \& Pons D. (2000). Experiencia escolar y orientación hacia la autoridad institucional en la adolescencia [School experiences and orientation towards institucional authority in adolescence]. Revista de Psicología Social, 15, 199-217. http://dx.doi.org/10.1174/021347400760259820

Moos R. M., Moos B. S., \& Trickett E. J. (1984). FES, WES y CES. Escalas de Clima Social [FES, WES, and CES. School Environment Scales]. Madrid, Spain: TEA Ediciones.

Moreno D., Estévez E., Murgui S., \& Musitu G. (2009). Reputación social y violencia relacional en adolescentes: el rol de la soledad, la autoestima y la satisfacción vital [Social reputation and relational violence in adolescents: the role of loneliness, self-esteem, and life satisfaction]. Psicothema, 21, 537-542.

Murray C., \& Murray K. M. (2004). Child level correlations of teacher-students relationships: An examination of demographic orientation characteristics, academia orientations, and behavioral orientations. Psychology in the Schools, 41, 751-762. http://dx.doi.org/10.1002/ pits.20015

Musitu G., Estévez E., \& Emler N. (2007). Adjustment problems in the family and school context, attitude towards authority, and violent behavior at school in adolescence. Adolescence, 42, 779-794.

Mynard H., \& Joseph S. (2000). Development of the multidimensional Peer Victimization Scale. Aggressive Behavior, 26, 169-178. http://dx.doi.org/10.1002/ (SICIhttp://dx.doi.org/10.1002/(SICI)1098- 2337(2000)26:2<169::AID-AB3>3.3.CO;2-1

Olweus D. (2001). Olweus's core program against bullying and antisocial behavior: A teacher handbook. Bergen, Norway: Research Centre for Health Promotion.

Paul J. J., \& Cillessen A. H. N. (2003). Dynamics of peer victimization in early adolescence: Results from a four-year longitudinal study. Journal of Applied School Psychology, 19, 25-43. http://dx.doi.org/10.1300/J008v19n02_03

Peleg-Popko O., \& Klingman A. (2002). Family environment, discrepancies between perceived actual and desirable environment, and children's test and trait anxiety. British Journal of Guidance and Counselling, 30, 451-466. http://dx.doi.org/10.1080/0306988021000025646

Reicher S., \& Emler N. (1985). Delinquent behavior and attitudes to formal authority. British Journal of Social Psychology, 3, 161-168. http://dx.doi.org/10.1111/j.2044-8309.1985.tb00677.x

Reinke W. M., \& Herman K. C. (2002). Creating school environment that deter antisocial behaviors in youth. Psychology in the Schools, 39, 549-559. http://dx.doi. org/10.1002/pits.10048

Ritakallio M., Kaltiala-Heino R., Kivivuori J., \& Rimpelä M. (2005). Brief report: Delinquent behavior and depression in middle adolescence: A Finnish community sample. Journal of Adolescence, 28, 155-159. http://dx.doi.org/10.1016/j.adolescence.2004.07.002

Samdal O. (1998). The school environment as a risk or resource for students' health-related behaviors and subjective well-being. Bergen, Norway: University of Bergen.

Sampson R. J., \& Lauritsen J. L. (1990). Deviant lifestyles, proximity to crime, and the offender-victim link in personal violence. Journal of Research in Crime and Delinquency, 27, 110-139. http://dx.doi.org/10.1177/0022427890027002002

Shaffer J. N., \& Ruback R. B. (2002). Violent victimization as a risk factor for violent offending among juveniles. Washington, DC: OJJDP Juvenile Justice Bulleting. Department of Justice, Office of Juvenile Justice and Delinquency Prevention.

Sheeber L., Hops H., Alpert A., Davis B., \& Andrews J. (1997). Family support and conflict: Prospective relations to adolescent depression. Journal of Abnormal Child Psychology, 25, 333-345. http://dx.doi.org/10.1023/A:1025768504415

Skiba R. J. (2000). Zero tolerance. Zero evidence. An analysis of school disciplinary practice. Bloomington, IN: Indiana Education Policy Center.

Smith P. K. (Ed.). (2003). Violence in schools: The response in Europe. London, UK: Routledge Falmer. 
Snyder H., \& Sickmund M. (1999). Juvenile offenders and victims: 1999 national report. Washington, DC: Office of Juvenile Justice and Delinquency Prevention.

Stevens V., De Bourdeaudhuij I., \& van Oost P. (2002). Relationship of the family environment tochildren's involvement in bully/victim problems at school. Journal of Youth and Adolescence, 31, 419-428.

http://dx.doi.org/10.1023/A:1020207003027

Storch E. A., \& Masia-Warner C. (2004). The relationship of peer victimization to social anxiety and loneliness in adolescent females. Journal of Adolescence, 27, 351-362. http://dx.doi.org/10.1016/S0140-1971(04)00035-1

Sullivan T., Farrell A. D., \& Kliewer W. (2006). Peer victimization in early adolescence: Association between physical and relational victimization and drug use, aggression, and delinquent behaviors among urban middle school students. Development and Psychopathology, 18, 119-137. http://dx.doi.org/10.1017/S095457940606007X

Sweeting H., Young R., West P., \& Der G. (2006). Peer victimization and depression in early-mid adolescence: A longitudinal study. British Journal of Educational Psychology, 76, 577-594. http://dx.doi.org/10.1348/ 000709905X49890

Tarry H., \& Emler N. (2007). Attitudes, values and moral reasoning as predictors of delinquency. British Journal of Developmental Psychology, 25, 169-183. http://dx.doi. org/10.1348/026151006X113671

Underwood M. K. (2003). Social aggression among girls. New York, NY: Guildford Press.

U.S. Department of Health and Human Services. (2001). Youth violence: A report of the surgeon general. Rockville, MD: Government Printing Office.

Wiebush R., Freitag R., \& Baird C. (2001). Preventing delinquency through improved child protective services. Washington, DC: OJJDP Juvenile Justice Bulleting. Department of Justice, Office of Juvenile Justice and Delinquency Prevention. 